\title{
ANALYSIS OF THE SOIL CONDITIONS FOR THE MOVEMENT OF VEHICLES
}

Sylwia Borkowska1, Krzysztof Pokonieczny ${ }^{1}$

${ }^{1}$ Faculty of Civil Engineering and Geodesy, Military University of Technology in Warsaw, 00-908, Poland

Correspondence to: Sylwia Borkowska1 (sylwia.borkowska@wat.edu.pl)

https://doi.org/10.31490/9788024845050-3

\section{Abstract}

The passability of terrain is an important element of off-road navigation. The article presents the results of the analysis of soil passability classification using field measurements and soil spatial databases. The most detailed cartographic data available in Poland were used: a soil-agricultural map at scale 1:25,000. Maps concerning the passability of soils were developed by conducting field measurements with specialized equipment - a cone penetrometer and taking into account the type of vehicle and the number of its passes in the analyzed area. For this purpose, two indicators were used: the Cone Index $(\mathrm{Cl})$ and the Vehicle Cone Index $(\mathrm{VCl})$. The passability of soils was classified according to 3 classes (GO, SLOW-GO and NO-GO TERRAIN). The developed maps were analyzed, which showed that there are very good conditions of passability in the studied area. Nevertheless, this condition significantly changes with the increase in the number of passes of the analyzed vehicle. The developed maps may be a necessary study used for the movement of heavy vehicles in open areas and those difficult to access in the activities of crisis management units.

Keywords: terrain classification, soil passability, map of passability, off-road navigation

\section{INTRODUCTION}

A particularly important aspect in conducting rescue operations in open terrain is determining the possibility of heavy vehicles moving across the cross-country without the risk of immobilizing these vehicles in the field. According to standardization documents (NO-06-A015:2012 Terrain - Rules of Classification - Terrain Analysis on Operational Level, 2012), passability is a attribute of terrain that determines the possibility of vehicle movement outside the transport network. In the literature, there are many of articles dealing with issues related to terrain passability: study presenting modeling and assessment of terrain passability (Dohnal et al., 2017), (Hubacek et al.,2016), methods of developing terrain passability maps (Pokonieczny, 2017, Pokonieczny, \& Borkowska, 2019), and analyzing in detail individual parameters influencing passability through vegetation (Rybansky, 2020).

The aim of the research was to analyze the influence of soil conditions, used to classify the area in terms of passability using the field measurement, which was carried out in open, undeveloped areas using specialized equipment - a cone penetrometer (Field manual 5430-00-1, Planning and design of roads, airfields, and heliports in the theater of operations 
- road design, 1994).

Two factors were used to determine the terrain passability for heavy vehicle using field measurements:

- soil resistance obtained via a standardized passability cone penetrometer, expressed as the Cone Index $(\mathrm{Cl})$,

- pressure exerted on the soil by vehicles, expressed as the Vehicle Cone Index $(\mathrm{VCl})$.

\section{METHODOLOGY}

An important element in determining the passability of terrain in open areas is the conducting of field measurements with specialized equipment - an electronic cone penetrometer with a built-in probe for measuring soil moisture - Fig.1. The research used the measured value of soil resistance, defined as the Cone Index, on selected representative soil samples. The selected measurement sites were characterized by a variety of soil types, which made it possible to transfer the obtained results to other areas with the same soil type. The soil penetration resistance was measured in two periods: March-May (spring) and September-November (autumn).

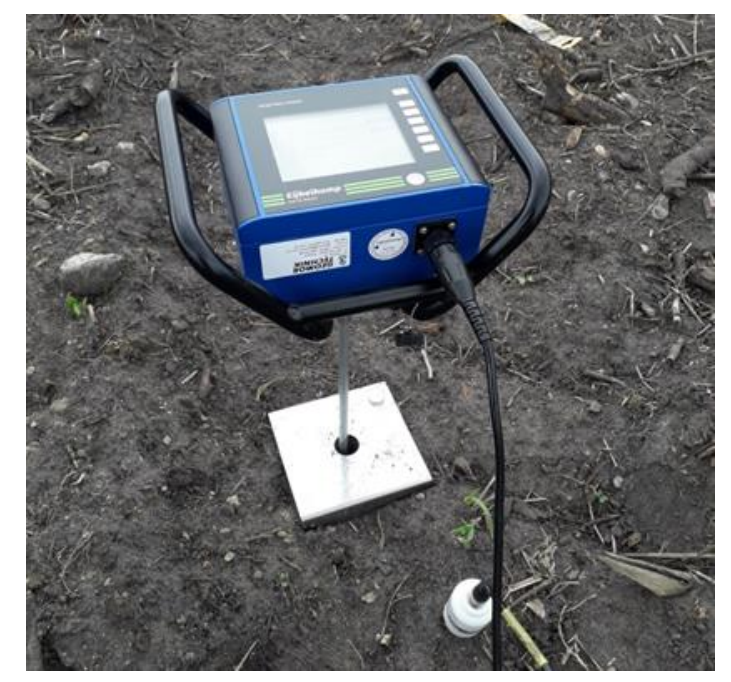

Fig. 1. Field measurement of the Cone Index using an electronic cone penetrometer

On each measuring point (soil representative sample), the full Cone Index measurement was carried out according to the test procedures (Stevens et al., 2013):

- The cone was pressed evenly into the soil (at a speed of $2 \mathrm{~cm} / \mathrm{s}$ ). The $\mathrm{Cl}$ value was calculated as the average measurement of soil resistance at depths of 1, 15, 30 and $45 \mathrm{~cm}$.

- Six individual measurements were made in a circle with a diameter of $1 \mathrm{~m}$.

Soil database informing about the range of a given type of soil was obtained from a soilagricultural map in the scale of $1: 25,000$. These are the most detailed spatial data found in the National Geodesy and Cartography Resource, concerning the variability of the soils in 
Poland. The soil-agricultural map contains synthetic information on the physical properties of the soil: the separation of soil contours along with the attributes defining the soil grain size groups and subgroups, which were used in the passability analysis (Regional Surveying and Cartographic Documentation Centre).

In the study of the soil passability, 19 subgroups of soil grain sizes belonging to gravel, sandy, clay, silty, loamy and peaty soils were used. Field measurements were carried out for selected representative soil samples at 70 measurement sites in the Masovian Voivodeship in Poland. Four measurement campaigns were carried out in each measurement period. For measurements in spring and autumn, the standard deviation did not exceed $0.2 \mathrm{MPa}$. The obtained average $\mathrm{Cl}$ values for each measuring period are presented in Table 1.

Table 1. Soil penetrometric resistance values.

\begin{tabular}{ccccc}
\hline \multirow{2}{*}{$\begin{array}{c}\text { Group of soil } \\
\text { grain sizes }\end{array}$} & \multicolumn{2}{c}{$\begin{array}{c}\text { Spring measurement period } \\
\text { (March-May) }\end{array}$} & \multicolumn{2}{c}{$\begin{array}{c}\text { Autumn measurement period } \\
\text { (September-November) }\end{array}$} \\
\cline { 2 - 5 } & $\begin{array}{c}\text { Cone Index CI } \\
{[\mathrm{MPa}]}\end{array}$ & $\begin{array}{c}\text { Average soil } \\
\text { moisture [\%] }\end{array}$ & $\begin{array}{c}\text { Cone Index CI } \\
{[\mathrm{MPa}]}\end{array}$ & $\begin{array}{c}\text { Average soil } \\
\text { moisture [\%] }\end{array}$ \\
\hline clay & 0.80 & 21.32 & 1.02 & 20.78 \\
\hline silty & 0.83 & 29.74 & 0.90 & 22.50 \\
\hline sandy & 0.94 & 29.93 & 1.00 & 21.04 \\
\hline loamy & 0.58 & 48.91 & 0.65 & 45.00 \\
\hline peaty & 0.53 & 65.38 & 0.47 & 57.86 \\
\hline
\end{tabular}

Additionally, the value of the r-Pearson correlation coefficient for two variables for the tested 19 subgroups of soil grain sizes was calculated: the Cone Index and soil moisture. A strong correlation was shown between the studied values:

- spring period: -0.63 ,

- autumn period: -0.70 .

To determine the passability of terrain for vehicles, the pressure exerted on the soil by vehicles, expressed as the Vehicle Cone Index ( $\mathrm{VCl}$ ), is also used. Based on the collected research results, the calculation methods of $\mathrm{VCl}$ estimation for wheeled and tracked vehicles were developed (Field manual 5-430-00-1 Planning and design of roads, airfields, and heliports in the theater of operations - road design, 1994). In the case of heavy vehicles, the pressure forces are significant - the estimated values of $\mathrm{VCl}$ are presented below in Table 2: for a one pass - $\mathrm{VCl}(1)$, and for multiple passes of the vehicle on one track - VCI(50) (User manual, 06.15.SA). The soil passability analysis included an AWD truck vehicle, for which the $\mathrm{VCl}$ (1) value is in the range of $0.24-0.30 \mathrm{MPa}$, and the $\mathrm{VCl}$ (50) value in the range of $0.55-0.88 \mathrm{MPa}$. 
Table 2. Estimated VCI values for selected vehicles (User manual, 06.15.SA).

\begin{tabular}{ccc}
\hline \multicolumn{2}{c}{ Range of the VCI [MPa] } & Vehicle type \\
\cline { 1 - 2 } VCI $(1)$ & $\mathrm{VCI}(50)$ & $\begin{array}{c}\text { AWD single trucks } \\
\text { (light pressure) }\end{array}$ \\
\hline $0.21-0.24$ & $0.48-0.55$ & Most AWD trucks \\
\hline $0.24-0.30$ & $0.55-0.88$ &
\end{tabular}

Using data on soil penetrometric resistance $(\mathrm{Cl})$ and unit pressure of vehicles $(\mathrm{VCl})$, the class of soil passability was determined in accordance with the following rule:

- The $\mathrm{Cl}$ value is lower than the $\mathrm{VCl}$ value - The area is impassable and is referred to as NO-GO TERRAIN. Vehicles will "sink" to a depth where the $\mathrm{Cl}$ value is equal to or greater than the $\mathrm{VCl}$ value.

- The $\mathrm{Cl}$ value is within the range of $\mathrm{VCl}$ values - The terrain is difficult to pass and is referred to as SLOW-GO TERRAIN. Vehicles will tend to leave marks.

- The $\mathrm{Cl}$ value is greater than the $\mathrm{VCl}$ value - Terrain is passable and referred to as GO TERRAIN. The passability will be the greater the more the $\mathrm{Cl}$ value exceeds the $\mathrm{VCl}$ value.

\section{RESULTS}

To develop the maps of soil passability the Statistica 10 program and the GIS tool - the ArcMap 10.5 were used. In accordance with the described rule of determining the passability, consisting in comparing the $\mathrm{VCl}$ and $\mathrm{Cl}$ values, the attributes of the analyzed soil types from the soil-agricultural map were assigned the appropriate values: GO TERRAIN, SLOW-GO TERRAIN or NO-GO TERRAIN.

As a result of the research, 4 maps of soil passability in the study area were developed, in various variants related to the number of passes of the analyzed vehicle and the period of field measurements. Additionally, 2 maps for average soil passability conditions were also developed - the values of the Cone Index for the analyzed measurement periods were averaged.

Figure 2 shows the developed soil passability maps for the analyzed AWD truck. The individual colors represent the following soil passability categories: green - GO TERRAIN, yellow - SLOW-GO TERRAIN, red - NO-GO TERRAIN. In the case of areas excluded from the analysis due to the lack of information on soil type, gray filling was used. 


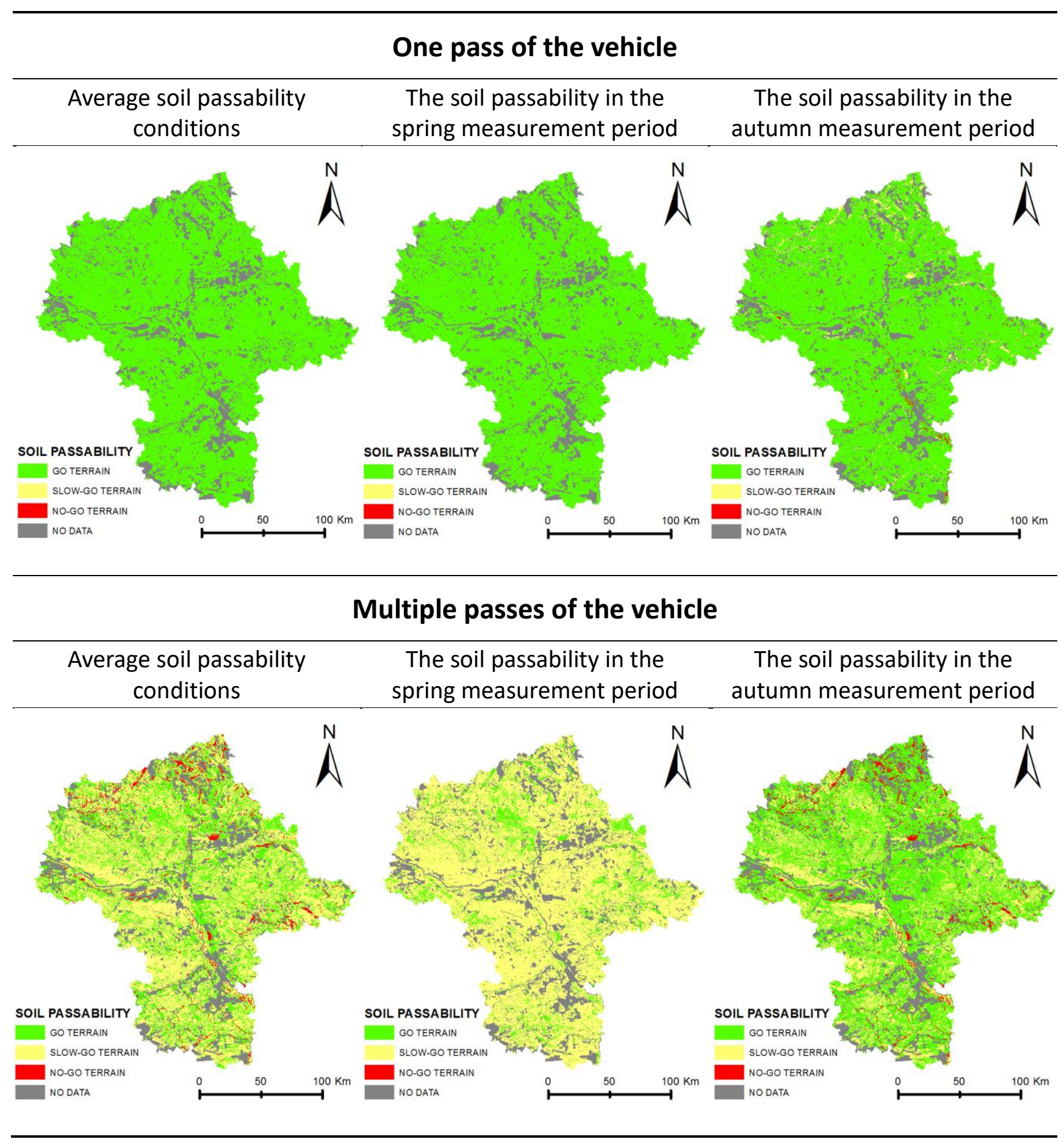

Fig. 2. Maps of soil passability in the Masovian Voivodeship for the analyzed variants

The obtained results of soil passability classification, relating to the area of the Masovian Voivodeship, are presented in Table 3. 
Table 3. Summary of the percentage share of the soil passability classification in the analyzed area.

\begin{tabular}{ccccccc}
\hline \multirow{2}{*}{$\begin{array}{c}\text { Soil } \\
\text { passability } \\
\text { class }\end{array}$} & \multicolumn{3}{c}{$\begin{array}{c}\text { Soil passability for one pass } \\
\text { of the vehicle [\%] }\end{array}$} & \multicolumn{3}{c}{$\begin{array}{c}\text { Soil passability for multiple passes } \\
\text { of the vehicle [\%] }\end{array}$} \\
\cline { 2 - 7 } & Average & $\begin{array}{c}\text { Spring } \\
\text { measurement } \\
\text { period }\end{array}$ & $\begin{array}{c}\text { Autumn } \\
\text { measurement } \\
\text { period }\end{array}$ & Average & $\begin{array}{c}\text { Spring } \\
\text { measurement } \\
\text { period }\end{array}$ & $\begin{array}{c}\text { Autumn } \\
\text { measurement } \\
\text { period }\end{array}$ \\
\hline $\begin{array}{c}\text { GO } \\
\text { TERRAIN }\end{array}$ & 81.6 & 81.6 & 77.8 & 29.8 & 11.7 & 52.6 \\
\hline $\begin{array}{c}\text { SLOW-GO } \\
\text { TERRAIN }\end{array}$ & 0.0 & 0.0 & 3.2 & 48.3 & 69.9 & 25.2 \\
\hline $\begin{array}{c}\text { NO-GO } \\
\text { TERRAIN }\end{array}$ & 0.0 & 0.0 & 0.6 & 3.5 & 0.0 & 3.8 \\
\hline NO DATA & 18.4 & 18.4 & 18.4 & 18.4 & 18.4 & 18.4 \\
\hline
\end{tabular}

\section{CONCLUSION}

The aim of the article was to analyze the passability of soils in the context of the movement of vehicles with specific characteristics in open areas and off-road using field measurements, available soil spatial database and GIS tools.

On the basis of the developed maps, it can be seen that in the case of increasing the number of passes of the analyzed vehicle, the conditions of soil passability deteriorate significantly. Assuming one pass, the analyzed area was almost entirely classified as GO TERRAIN. If the number of passes of a given vehicle is increased, this area is mostly classified as SLOW-GO TERRAIN.

The highest values of the Cone Index, and thus the best conditions of passability, were achieved for clay, silty and sandy soils. The exception is permanently wet soils such as peat. Penetrometric measurements confirmed the assumptions about favorable conditions of passability in the analyzed area. In addition, it was confirmed that soil moisture is an important factor affecting the degree of passability. This impact is presented not only in the form of a high correlation coefficient between soil moisture and the $\mathrm{Cl}$ value, but is also visible on the developed soil passability maps.

The developed maps of soil passability, taking into account the type of vehicle and the number of its passes in the analyzed area, provide more realistic results of the movement in open areas. Along with the remaining elements of land cover and topography, the prepared soil passability maps will constitute a complete study of the passability of the terrain, which is important in the context of off-road navigation.

\section{REFERENCES}

Dohnal, F., Hubacek, M., Sturcova, M., Bures, M. and Simkova, K. (2017) Identification of Microrelief Shapes Along the Line Objects Over DEM Data and Assessing Their Impact on the Vehicle Movement, Proceedings of the International Conference on Military Technology (ICMT) 2017, 31 May-2 June, Brno, pp. 262-267.

Field manual 5-430-00-1 (1994) Planning and design of roads, airfields, and heliports in 
the theater of operations - road design. Headquarters, Department of the Army, USA.

Hubacek, M., Ceplova, L., Brenova, M., Mikita, T. and Zerzan, P. (2015) Analysis of vehicle movement possibilities in terrain covered by vegetation. Proceedings of the International Conference on Military Technologies (ICMT) 2015, 19-21 May, Brno, pp. $1-5$.

Hubacek, M., Kovarik, V., Talhofer, V., Rybansky, M., Hofmann, A, Brenova, M. and Ceplova, L. (2016) Modelling of geographic and meteorological effects on vehicle movement in the open terrain. Proceedings of the 23rd Central European Conference, Brno, pp. 149-159.

NO-06-A015:2012 (2012) Terrain - Rules of Classification - Terrain Analysis on Operational Level. Polish Ministry of National Defence, Warsaw, Poland.

Pokonieczny, K. (2017) Automatic military passability map generation system. Proceedings of the 2017 International Conference on Military Technologies (ICMT) 2017, 31 May-2 June, Brno, pp. 285-292.

Pokonieczny, K., Borkowska, S. (2019) Using high resolution spatial data to develop military maps of passability. Proceedings of the International Conference on Military Technologies (ICMT) 2019, 30-31 May, Brno, pp. 1-8.

Regional Surveying and Cartographic Documentation Centre, http://wgik.dolnyslask.pl/wodgik/zasob/opracowania-tematyczne/mapa-gleboworolnicza (accessed on Feb 04, 2021).

Rybansky, M. (2020) Determination the ability of military vehicles to override vegetation, Journal of Terramechanics, 91, pp. 129-138.

Stevens, M. T., Towne, B.W., Mason, G. L., Priddy, J. D., and Osorio, J. E. (2013) Procedures for One-Pass Vehicle Cone Index (VCl1). Determination for Acquisition Support. Rep. No. ERDC/GSL SR-13-2. Vicksburg, MS: US Army Corps of Engineers Research and Development Center.

User manual 06.15.SA GEOMOR TECHNIK https://geomor.com.pl/wpcontent/uploads/2017/05/06.15.SA-Penetrologger-nowy.pdf (accessed on Feb 04, 2021). 